\title{
ASPEK PERLINDUNGAN HUKUM TERHADAP PEKERJA WANITA (Menurut Undang-Undang Nomor. 13 Tahun 2003).
}

\author{
Joupy G.Z. Mambu \\ Program Studi Ilmu Hukum Universitas Negeri Manado \\ E-Mail : joupymambu@yahoo.co.id
}

\begin{abstract}
Abstrak
The total number of job seekers has been growing in recent years. It is not only men who are seeking for job vacancy, but also women. This situation is getting harder for people to be employed particulalry women workers. This research applied normative-juridical analysis in analyzing secondary and tertiary data. The result shows that regulation Number 13, year 2003 on labor is considered unsufficient in terms of women workers protection. In this regulation, there are only five verses which specially accommodate women workers.

Jumlah angka pencari kerja dari tahun ke tahun terus meningkat. Selain pencari kerja pria yang terus bertambah, di sisi lain tenaga kerja wanita juga terus meningkat. Kondisi ini tentu saja akan semakin mempersulit dalam memperoleh pekerjaan, terutama pencari kerja wanita. Penelitian ini menggunakan analisis yuridis normatif yang mengkaji sumber hukum primer dan sekunder. Hasil analisa dalam penelitian ini mengungkapkan bahwa UU No. 13 Tahun 2003 tentang ketenagakerjaan dirasa masih kurang memadai dalam hal perlindungan terhadap tenaga kerja wanita. Dalam UU No. 13 Tahun 2003 Tentang Ketenagakerjaan hanya ada 5 pasal yang secara khusus mengatur mengenai tenaga kerja wanita.
\end{abstract}

Kata kunci: Perlindungan Hukum, Tenaga Kerja Wanita, Hak Tenaga Kerja Wanita

Tenaga kerja wanita yang potensial berada pada posisi tersulit, hal ini dapat terjadi antara lain di sebabkan masih kentalnya budaya patriarki, walaupun isu persamaan gender, hak dan kebebasan mengembangkan diri telah dikenal dan beredar di tengahtengah masyarakat, namun tetap saja masih ditemui adanya praktik-praktik diskriminasi. Pendapat yang beranggapan pria adalah sosok yang superior dalam segala hal masih banyak ditemukan bahkan masih ada di dalam dunia kerja. Salah satu efek negatif dari pendapat yang menganggap bahwa pria merupakan sosok yang superior adalah dominasi akan penerimaan dan posisi strategis bagi tenaga kerja pria. Hal ini menghambat tenaga kerja wanita untuk mengembangkan diri.
Kondisi di atas sangat bertentangan dengan Pasal 5 dan Pasal 6 UU RI No. 13 Tahun 2003 yang mengatur Setiap pekerja memiliki kesempatan yang sama tanpa diskriminasi untuk memperoleh pekerjaan. Setiap pekerja berhak memperoleh perlakuan yang sama tanpa diskriminasi pengusaha (Pasal 6).

Fenomena lain yang tidak kalah rumitnya bagi wanita dalam mencari kerja adalah lemahnya penerapan perlindungan hukum terhadap tenaga kerja wanita. Meskipun telah ada organisasi pekerja yang khusus mengakomodir segala bentuk kepentingan pekerja dalam dunia kerja, namun oleh sebagian pihak dinilai belum maksimal dalam melaksanakan fungsinya, antara lain dalam hal perlindungan terhadap tenaga kerja wanita. Hal ini semakin diperburuk oleh masih 
lemahnya kemampuan dan pengetahuan secara personal, dari tenaga kerja wanita tentang haknya. Sementara di sisi lain ada orang-orang yang tidak bertanggung jawab yang memanfaatkan ketidaktahuan tersebut dan mengabaikan peraturan yang ada.

Penyebab utamanya adalah adanya kekuasaan dan ketidaksetaraan ekonomi serta pandangan keliru yang meluas dalam masyarakat, dimana posisi kaum laki-laki dianggap lebih tinggi daripada wanita. Pandangan ini kemudian membenarkan pemikiran bahwa tubuh wanita adalah objek seksual. ${ }^{1}$

Tenaga kerja wanita sebagai bagian yang tidak terpisahkan keberadaannya dari pekerja pada umumnya, memiliki karakter fisik dan psikis yang khas yang membedakan mereka dengan pria. Di masa mendatang wanita semakin dituntut untuk mandiri, jauh dari kesan lemah dan sebisa mungkin menyesuaikan diri dengan kondisi persaingan yang semakin berat.

Lembaga Bantuan Hukum Asosiasi Perempuan Indonesia untuk Keadilan (LBH APIK) pada tahun 2005 menerima 16 kasus yang berkaitan dengan kasus ketenagakerjaan dengan perincian 1 kasus mutasi sepihak, 1 kasus kejahatan dalam jabatan, 3 kasus peraturan perusahaan yang merugikan, 2 kasus upah yang tidak dibayar, 1 kasus berkaitan dengan jasa tenaga kerja, $3 \mathrm{ka}$ sus PHK sepihak dan 5 kasus Tenaga Kerja Wanita di luar negeri. Sedangkan sepanjang tahun 2006, LBH APIK melakukan pendampingan hukum terhadap 24 kasus kekerasan seksual, dengan perincian 4 kasus pelecehan seksual, 4 kasus pencabulan 15 kasus perkosaan dan 1 kasus percobaan perkosaan.

Masalah Tenaga kerja wanita yang telah disampaikan di atas adalah sebagian kecil dari permasalahan-permasalahan pekerja yang ada. Permasalahan-permasalahan tersebut akan semakin tak terhitung jumlahnya jika kita benar-benar serius untuk menyimaknya hingga ke pelosok daerah. Setiap harinya berbagai media massa, baik cetak maupun elektronik tidak pernah sepi ${ }^{1}$ Ganjar Kusuma 2007: Pelecehan seksual di tempat kerja. sumber http//www.hukumonline.com dari pemberitaan tentang fenomena kesejahteraan ketenagakerjaan, yang tentu saja ini mengindikasikan bahwa masalah kesejahteraan harus mendapat perhatian yang sangat serius.

\section{Konsep Perlindungan Hukum}

Perlindungan hukum diartikan sebagai serangkaian tindakan dalam bentuk jaminan kepada subyek hukum, dalam upaya memberikan kepastian dan supremasi hukum. Sehingga diharapkan pihak tenaga kerja dapat terhindar dari perbuatan pengusaha yang melanggar hukum dan tidak bertanggung jawab. Selain itu tidak dapat dipungkiri Peran serta pekerja dalam pembangunan nasional adalah penting dengan disertai berbagai tantangan dan risiko yang dihadapinya.

Dalam rangka memberikan perlindungan hukum, maka secara khusus dalam UU No. 13 Tahun 2003 pada bagian penjelasan umum disebutkan: Perlindungan hukum terhadap pekerja, termasuk perlindungan atas hakhak dasar pekerja untuk berunding dengan pengusaha, perlindungan keselamatan, dan kesehatan kerja, perlindungan khusus bagi tenaga kerja wanita, anak, dan penyandang cacat, serta perlindungan tentang upah, kesejahteraan, dan jaminan sosial pekerja

Di dalam negara hukum Pancasila, perlindungan hukum bagi pekerja diarahkan kepada usaha-usaha untuk mencegah terjadinya sengketa antara pengusaha dan pekerja, menyelesaikan sengketa antara pengusaha dan pekerja secara musyawarah serta peradilan merupakan sarana terakhir dalam usaha menyelesaikan sengketa pengusaha dan pekerja.

Dengan adanya UU No. 13 Tahun 2003, menurut Kusmana, sesungguhnya tidak semata-mata memberikan perlindungan terhadap hak-hak perseorangan, tetapi juga sekaligus melindungi hak-hak masyarakat, yang menimbulkan kewajiban-kewajiban. ${ }^{2}$ Jadi perlindungan hukum terhadap pekerja tidak hanya mengutamakan individualisme melainkan juga secara komunal kelompok Sebagai cara untuk menyelaraskan kepen${ }^{2}$ Ibid..., h. 5 
tingan dan peranan pribadi individu dengan kepentingan masyarakat.

Selanjutnya dalam UU No. 13 Tahun 2003 Pasal 86 ayat (1) disebutkan bahwa Setiap pekerja mempunyai hak untuk memperoleh perlindungan atas: a) Keselamatan dan kesehatan kerja, b) Moral dan kesusilaan, c) Perlakuan yang sesuai dengan harkat dan martabat manusia serta nilai-nilai agama.

Sebelum adanya UU Ketenagakerjaan No. 13 Tahun 2003, peraturan Perundang-Undangan yang memberikan perlindungan hukum terhadap pekerja sangat minim. Walaupun diakui bahwa pengaturan perlindungan hukum dalam Undang-undang Ketenagakerjaan No 13 Tahun 2003 belum menjawab semua permasalahan yang begitu luas dan kompleks, namun setidak-tidaknya selangkah lebih maju dan diharapkan dapat memberikan perlindungan hukum terhadap pekerja terutama yang menyangkut syaratsyarat kerja, kondisi kerja serta jaminan sosial dan perlindungan kerja lainnya serta dapat dijadikan acuan dalam penyelesaian perselisihan hubungan industrial.

Penyelenggaraan perlindungan hukum, pemeliharaan dan peningkatan kesejahteraan merupakan tanggung jawab dan kewajiban negara. Manfaat perlindungan hukum tersebut dapat memberikan rasa aman kepada pekerja sehingga dapat lebih berkonsentrasi dalam meningkatkan motivasi maupun produktivitas kerja.

\section{Konsep Tenaga Kerja Wanita.}

Penyebutan istilah buruh terhadap orang yang bekerja pada orang lain telah dipakai jauh sebelum bangsa Indonesia merdeka. Yang buruk dari penyebutan ini adalah sulitnya menghindari konotasi negatif yang seakan-akan melekat dengan sendirinya dan tidak bisa dipisahkan lagi. Hampir semua orang yang mendengar istilah buruh akan selalu berpikir tentang segolongan pekerja kasar yang selalu ditekan dan berada pada posisi di bawah pihak lain.

Konotasi yang negatif tersebut maka penyebutan istilah buruh di dalam undang-undang diganti dengan istilah pekerja. Menu- rut Pasal 1 Angka 3 UU RI No. 13 Tahun 2003 Pekerja adalah setiap orang yang bekerja dengan menerima upah atau imbalan dalam bentuk lain.

Dari definisi di atas terdapat dua unsur pokok yaitu unsur orang yang bekerja dan unsur menerima upah atau imbalan dalam bentuk lain. Istilah pekerja diupayakan diganti dengan istilah pekerja karena istilah pekerja dipandang kasar dan kurang sesuai dengan kepribadian bangsa.

Selanjutnya UU RI No. 3 Tahun 1992 tentang Perlindungan Sosial Pekerja pada Pasal 8 dalam hal kepentingan santunan jaminan kecelakaan kerja, pengertian pekerja diperluas yaitu: a) Magang dan murid yang bekerja pada perusahaan baik yang menerima upah maupun tidak, b) Mereka yang memborong pekerjaan kecuali jika yang memborong adalah perusahaan, c) Narapidana yang dipekerjakan diperusahakan.

Secara garis besar ada tiga motivasi yang mendorong wanita untuk turut serta dalam lapangan pekerjaan yaitu: 1) Faktor ekonomi yaitu untuk mencari tambahan pendapatan, 2) Faktor sosial yaitu meningkatkan status sosial dalam masyarakat., 3) Aktualisasi diri terhadap keluarga dan masyarakat. ${ }^{3}$

Menurut Tatty problematika pekerja wanita ada 2 faktor yaitu: Pertama, Faktor Internal: a) Diri sendiri, menggambarkan mental atau kondisi psikologis wanita tersebut dalam menghadapi problematika yang ada, b) Tingkat pendidikan, semakin tinggi syarat pendidikan dan keterampilan untuk para pekerja wanita dalam meniti karier, c) Lingkungan keluarga, Dukungan dari keluarga sangat penting bagi seorang wanita karena keluarga yang terbuka, demokratis dan modern lebih cenderung mendukung wanita bekerja, d) Kesehatan. Masalah kesehatan wanita berbeda dengan pria karena masalah kesehatan wanita berpengaruh kepada dirinya sendiri juga berpengaruh kepada kondisi janin jika dia sedang hamil. Kedua, Faktor Eksternal: a) Lingkungan sosial, Nilai-nilai sosial yang ada hanya sete-

\footnotetext{
${ }^{3}$ Hanartani 2002, Tajuk Rencana Hukum Perlindungan Tenaga Kerja Wanita. Sumber:http//www
} 
ngah hati memberikan peluang kepada wanita untuk maju, sebagai contoh: pilot selalu identik dengan pria. Wanita juga dihadapkan dengan adanya pandangan negatif dari sebagian masyarakat terhadap wanita yang pulang malam. b)Lingkungan kerja, Kultur dan budaya membentuk ego pria yang kuat dan kokoh sehingga dunia luar rumah tangga dikukuhkan sebagai milik pria.

\section{Konsep Hak}

Penghormatan terhadap hak-hak manusia memerlukan proses panjang mengingat sifat hak-hak manusia yang sarat akan nilainilai moral. Dalam mewujudkan perlindungan dan penghormatan hak-hak manusia tersebut, telah banyak peraturan-peraturan hukum yang dibuat, termasuk peraturan di bidang ketenagakerjaan. Begitu pun juga dalam mengawal peraturan tersebut tidak sedikit organisasi yang dibentuk baik itu LSM swasta maupun badan-badan yang dibentuk oleh pemerintah.

Secara sederhana hak dapat dirumuskan sebagai suatu kekuatan/kekuasaan atau kewenangan yang diatur oleh hukum dan kekuasaan itu didasarkan pada kesusilaan (moral) dan tidak hanya kekuatan fisik saja. Sedangkan Kekuasaan atau kewenangan itu sendiri lahir dikarenakan oleh adanya hubungan hukum.

Apeldoorn mengatakan, yang disebut hak adalah hukum yang dihubungkan dengan seorang manusia atau subyek hukum tertentu dan dengan demikian menjelma menjadi suatu kekuasaan, dan suatu hak timbul apabila hukum mulai bergerak. ${ }^{4}$

Selanjutnya hak dapat digolongkan ke dalam dua golongan besar yaitu: Pertama, Hak mutlak (Absolut rechten), Hak mutlak adalah setiap kekuasaan mutlak yang diberikan kepada subyek hukum untuk berbuat sesuatu/bertindak dalam mengurus kepentingannya. Hak mutlak ini antara lain hak asasi, hak publik absolut dan sebagian dari hak privat. Kedua, Hak relatif (Relative rechten), Hak relatif adalah setiap kekuasaan atau kewenangan yang oleh hukum diberikan ke${ }^{4}$ Apeldoorn, 1982: 11 pada subyek hukum tertentu supaya ia berbuat sesuatu, atau tidak berbuat sesuatu atau memberikan sesuatu.

Hak dapat timbul atau lahir karena beberapa sebab yaitu: 1) Karena adanya subyek hukum baru baik berupa orang atau badan hukum, 2) Karena adanya perjanjian yang disepakati oleh para pihak yang mengadakan perjanjian, 3) Karena adanya kerugian yang diderita oleh seseorang karena kesalahan orang lain, 4) Karena seseorang telah melaksanakan kewajiban yang merupakan syarat untuk memperoleh suatu hak, 5) Karena kadaluwarsa (verjaring) yang bersifat akuisitif yaitu yang dapat melahirkan hak bagi seseorang.

Sedangkan lenyap atau hapusnya hak dapat disebabkan oleh beberapa hal yaitu: 1) Karena meninggalnya pemegang hak, dan tidak adanya ahli waris dari pemegang hak yang meninggal tersebut, 2) karena masa berlakunya telah habis dan tidak diperpanjang, 3) Karena telah dipenuhinya kewajiban seseorang kepada pihak pemegang hak, 4) Berlakunya kadaluwarsa, 5) karena ketentuan undang-undang, 6) adanya peralihan kewajiban dari salah satu pihak ke pihak lain, 7) adanya sebab yang di luar kemampuan manusia, sehingga ia tidak dapat memenuhi kewajiban tersebut.

Diakui bahwa hak-hak asasi manusia bersifat universal dan masyarakat internasional juga telah mengakui dan menyepakati bahwa pelaksanaannya merupakan wewenang dan tanggung jawab pemerintah dengan memperhatikan sepenuhnya keanekaragaman tata nilai, sejarah, kebudayaan, sistem politik, tingkat pertumbuhan sosial dan ekonomi, serta faktor-faktor lain yang dimiliki bangsa yang bersangkutan.

\section{Metode Penelitian}

Jenis penelitian yang digunakan dalam penelitian ini adalah penelitian hukum normatif atau penelitian hukum kepustakaan (library research) (Soekanto dan Mamudji, 1995: 90). Penelitian hukum normatif mengkaji hukum yang dikonsepkan sebagai norma atau kaidah yang berlaku. Norma hukum yang 
berlaku itu berupa norma hukum positif tertulis berbentuk lembaga perundang-undangan (undang-undang dasar), kodifikasi, undang-undang, peraturan pemerintah dan sebagainya. $^{5}$

Penelitian tipe ini disebut sebagai "Studi Dogmatik", atau yang dikenal dengan Doctrinal Research. Penelitian tipe doctrinal (doctrinal research) adalah mirip dengan tipe penelitian hukum normatif. Penelitian hukum normatif disebut juga penelitian hukum teoritis/dogmatik hukum bersifat teoritis-rasional, sehingga pengungkapannya terikat pada metode yang di dasarkan pada persyaratan logika deduktif. Di samping itu, maka dogmatik hukum memperhitungkan kecermatan, ketetapan dan kejelasan. Penelitian hukum normatif atau penelitian hukum kepustakaan (library research) ini dilakukan dengan cara meneliti bahan-bahan pustaka atau data sekunder belaka. ${ }^{6}$

Pengumpulan data dilakukan melalui kegiatan studi kepustakaan dan studi dokumen. Data-data yang dikumpulkan dan digunakan dalam penulisan ini sumber dari: 1) Kaidah-kaidah hukum yang dianggap sesuai, baik itu kaidah hukum primer seperti UUD tahun 1945, kaidah hukum sekunder seperti hasil karya dari kalangan ahli hukum maupun kaidah hukum tersier yang berupa keterangan-keterangan yang mendukung bahan hukum primer dan sekunder, 2) Artikel-artikel, karya tulis ilmiah yang dianggap relevan dan pendapat para ahli sebagai penunjang penelitian ini.

Data-data tersebut di atas diperoleh melalui studi kepustakaan, melalui media cetak seperti surat kabar dan melalui media elektronik seperti televisi dan internet.

Data yang diperoleh dari sumber-sumber data, diolah secara kualitatif dengan metode berpikir deduktif normatif, yaitu metode berpikir dari hal yang bersifat umum kemudian menarik kesimpulan yang bersifat khusus, yaitu dari hasil penelitian yang diperoleh melalui penelitian kepustakaan disusun menjadi satu secara sistematis se-

${ }^{5}$ Muhammad, 2004: 86

${ }^{6}$ Soekanto dan Mamudji, 1995: 91 hingga saling melengkapi, dikaitkan dengan UU No. 13 Tahun 2003 dan peraturan lainnya yang mengatur mengenai perlindungan hukum terhadap pekerja wanita.

Data yang telah dikumpulkan peneliti, diolah dan disusun secara teratur, berurutan, logis, sehingga mudah dipahami dan diinterpretasikan. Kemudian data-data yang telah dikumpulkan, diseleksi dan dianalisis tersebut kemudian ditempatkan menurut kerangka sistematika atau pengelompokan sesuai objek penelitian yaitu apa yang menjadi titik perhatian dalam penelitian ini. Dengan demikian akan nampak data kualitatif hasil penelitian tentang perlindungan hukum bagi pekerja wanita.

Karena data dalam penelitian ini hanya berdasarkan data kepustakaan dan dokumentasi tanpa mengadakan penelitian lapangan, maka uraiannya bersifat kualitatif artinya data akan disajikan dalam bentuk kalimat-kalimat sehingga membentuk suatu teks. ${ }^{7}$

Penelitian ini juga memusatkan perhatiannya pada hukum sebagai sistem peraturanperaturan yang abstrak, hukum sebagai suatu lembaga yang benar-benar otonom, terlepas dari kaitannya dengan hal-hal di luar peraturan Perundang-Undangan. Menurut Muhammad, apabila penelitian itu menggunakan pendekatan normatif analitis substansi hukum (approach of lega icontent analysis), ada 3 (tiga) gradasi pendekatan normatif analisis yang dapat digunakan, yaitu: penjelajahan hukum (legal exploration); tinjauan hukum (legal review), dan analisis hukum atau analisis yuridis (legal analysis). Analisis yuridis adalah tingkatan tertinggi serta lebih komprehensif dalam kajian substansi hukum. ${ }^{8}$

Berdasarkan uraian tersebut di atas, karena data dalam penelitian ini bersifat data kualitatif, maka dalam penelitian ini menggunakan analisis yuridis normatif (hukum normatif). dengan melalui 3 gradasi (tingkat) pendekatan normatif analisis, yaitu: hukum (legal exploration), hukum (legal review), dan (c) analisis hukum atau analisis yuridis (legal analiysis).

\footnotetext{
${ }^{7}$ Hadikusuma, 1995: 79

${ }^{8}$ Muhammad, 200455
} 


\section{Hasil dan Pembahasan}

\section{Perjanjian Kerja dalam Kaitannya dengan Perlindungan Hukum Pekerja Wanita.}

Seiring dengan perjalanan waktu, secara perlahan-lahan wanita mendapat tempat setara dengan pria dalam beragam bidang pekerjaan. Bukan zamannya lagi seseorang dinilai kinerjanya berdasarkan jenis kelamin. Kemampuan dan keahlian individulah yang menentukan kesuksesan karier seseorang. Meski begitu, kodrat seorang wanita tak dapat dielakkan dan tetap punya tempat tersendiri yang harus dijaga. ${ }^{9}$ Karena itu, adanya kesepakatan kerja yang sesuai dengan undang-undang ketenagakerjaan dan perjanjian kerja sangat penting untuk dipahami. Baik pekerja wanita maupun pekerja pria, mengetahui setiap butir dalam undangundang dan perjanjian kerja adalah sebuah keharusan. Terkhusus untuk wanita, mengetahui dan memahami akan hak-hak dan kewajibannya dalam sebuah pekerjaan akan memberikan rasa nyaman dan kepastian hukum selama bekerja.

Perjanjian kerja bagi seorang karyawan baru adalah sangat penting karena di dalamnya, berisi pernyataan-pernyataan yang sangat mendasar yang berisi persetujuan para pihak untuk mengikuti segala kesepakatan. Dalam sebuah surat perjanjian kerja antara pihak perusahaan dan pekerja wanita setidak-tidaknya memuat tiga hal pokok mengenai perlindungan terhadap pekerja wanita, tiga hal pokok tersebut yaitu: Perta$m a$, Perlindungan yang bersifat proteksi, Perlindungan protektif bertujuan memberikan perlindungan terhadap fungsi reproduksi wanita. Wujudnya berupa pemberian istirahat pada waktu haid, hamil, melahirkan atau keguguran kandungan. Selain itu dengan memberikan kesempatan menyusui anak dalam waktu kerja. Perlindungan protektif juga diwujudkan dalam bentuk pengaturan waktu kerja malam bagi wanita, penyediaan kendaraan antar-jemput dan tambahan makanan dan minuman bergizi. Tak kalah penting adalah adanya perlindungan terhadap keamanan dan kesusilaan para pekerja. ${ }^{9}$ Pambudy, 2006: 15
Kedua, Perlindungan yang bersifat korektif, berupa pengawasan terhadap kemungkinan terjadinya pelarangan berupa pemutusan hubungan kerja (PHK) dengan alasan hamil, melahirkan, keguguran kandungan ataupun menyusui. Ketiga, Perlindungan mengenai kesetaraan memperoleh kesempatan kerja dan perlakuan tanpa diskriminasi diwujudkan dalam bentuk larangan diskriminasi dalam hal pengupahan, pekerjaan dan jabatan. Dalam hal ini, pengusaha tidak boleh membeda-bedakan antara laki-laki dan wanita dari segi upah, promosi jabatan dan hak atas jaminan sosial. ${ }^{10}$

Selanjutnya jika mengacu pada UU RI No. 13Tahun 2003, maka isi perjanjian kerja antara pihak perusahaan dan pihak pekerja wanita, maka isi perjanjian kerja minimal meliputi: a) Perjanjian perlindungan dalam hal kerja malam bagi pekerja wanita (pukul 23.00 sampai pukul 07.00). Dalam pelaksanaannya masih ada perusahaan yang tidak memberikan makanan dan minuman bergizi tetapi diganti dengan uang padahal ketentuannya tidak boleh diganti dengan uang, b) Perjanjian perlindungan terhadap pekerja wanita yang dalam masa haid tidak wajib bekerja pada hari pertama dan kedua pada waktu haid dengan upah penuh. Dalam pelaksanaannya lebih banyak yang tidak menggunakan haknya dengan alasan tidak mendapatkan premi hadir, c) Perjanjian perlindungan cuti hamil bersalin selama $1,5 \mathrm{bu}-$ lan sebelum saatnya melahirkan dan 1,5 bulan sesudah melahirkan dengan upah penuh. Ternyata dalam pelaksanaannya masih ada perusahaan yang tidak membayar upah secara penuh. d. Pemberian kesempatan pada pekerja wanita yang anaknya masih menyusu untuk menyusui anaknya hanya efektif untuk yang lokasinya dekat dengan perusahaan. ${ }^{11}$

Perjanjian kerja memiliki manfaat yang besar bagi para pihak yang terlibat dalam perjanjian tersebut. Perjanjian ini menjadi begitu penting karena dengan perjanjian kerja yang dibuat dan ditaati bersama akan da-

\footnotetext{
$\overline{{ }^{10} \text { Suksesyadi, 2008: } 11}$

${ }^{11}$ Raharjo dan Sitomurang, 2006: 52
} 
pat menciptakan ketenangan kerja, jaminan kepastian hak dan kewajiban baik bagi pihak pekerja maupun pengusaha (Huni, 2003: 10). Menurut UU No. 13 Tahun 2003 Pasal 1 butir 14 Perjanjian kerja adalah:

"Perjanjian antara pekerja/buruh dengan pengusaha atau pemberi kerja yang memuat syarat-syarat kerja, hak, dan kewajiban para pihak".

Selain pengertian di atas ada pengertian lain yang diberikan oleh Halim, menurut beliau:

“Perjanjian kerja adalah perjanjian yang diadakan antara pekerja dan majikan dimana mereka saling mengikat diri satu sama lain untuk bekerja sama dimana pekerja berjanji akan melaksanakan perintah majikan sebagai pekerjaannya dengan baik dan majikan akan menanggung kehidupan buruh (dan keluarganya) dengan baik pula, selaras dengan kemampuan dan persetujuan mereka masing-masing (Halim, 2002: 16)"

Di dalam Undang-undang No. 13 Tahun 2003 dibahas mengenai Ketenagakerjaan yang disebutkan bahwa hubungan kerja terjadi karena adanya perjanjian kerja antara pengusaha dan pekerja/ buruh. Dan diperkuat lagi terbitnya Undang-undang No. 2 Tahun 2004 mengenai Penyelesaian Perselisihan Hubungan Industrial yang memiliki dampak sangat besar dalam penanganan masalah-masalah perselisihan perburuhan di Indonesia.

Selanjutnya Raharjo dan Situmorang, menambahkan bahwa sebelum seorang calon pekerja menandatangani surat perjanjian kerja, maka terlebih dahulu harus memastikan bahwa isi perjanjian kerja tersebut telah memuat hal-hal sebagai: a) Ketentuan hak dan kewajiban antara pihak pertama yaitu perusahaan dan pihak kedua yaitu pekerja, b) Besarnya jumlah gaji yang telah disepakati, apakah akan diterima per bulan ataukah per hari, c) Benefit lain yang bisa didapatkan oleh seorang pekerja. Misalnya tunjangan JAMSOSTEK, ataupun ketentuan THR yang bisa diterima karyawan di kemudian hari, d) Ketentuan-ketentuan lain yang bersifat nor- matif seperti berbagai hak cuti. Entah itu cuti melahirkan, cuti tahunan, atau yang lainnya. Ketentuan jam kerja dan aturan main lainnya yang bisa juga termasuk hak dan kewajiban karyawan dalam perusahaan juga bisa dicantumkan. ${ }^{12}$

Jika poin-poin tersebut sudah tercantum di surat perjanjian kerja, maka perjanjian kerja tersebut dibuat rangkap dua dengan meterai yang cukup nilainya. Kedua belah pihak baik karyawan maupun perusahaan kemudian membubuhkan tanda tangan di atas perjanjian atau kontrak kerja yang telah disepakati. Dan Masing-masing pihak mendapatkan surat perjanjian yang asli.

Pengetahuan akan Undang-Undang tenaga kerja terutama pasal-pasal yang menyangkut pekerja wanita sebaiknya juga dibarengi dengan pemahaman terhadap aturan perusahaan secara detail. Antara lain, menyangkut perlindungan apa saja yang diberikan perusahaan. Hal ini sering luput dari perhatian karyawan. Yang kebanyakan hanya mementingkan butir kesepakatan kerja yang menyangkut gaji, atau paket asuransi yang disediakan, serta bonus-bonus tambahan yang tak jauh dari masalah nominal.

\section{Pelaksanaan Perlindungan Hukum Terhadap Pekerja Wanita Menurut UU No. 13 Tahun 2003.}

Pekerja/buruh adalah setiap orang yang bekerja dengan menerima upah atau imbalan dalam bentuk lain. Hal ini sesuai dengan Undang-Undang Nomor 13 tahun 2003, Pasal 1 tentang ketentuan-ketentuan umum mengenai pekerja. Wanita baik sebagai warga negara maupun sebagai pekerja yang turut andil dalam pembangunan mempunyai hak, kewajiban dan kesempatan yang sama dengan pria disegala bidang kehidupan bangsa dalam segenap kegiatan pembangunan. ${ }^{13}$

Demikian juga jika pekerja wanita yang bekerja di perusahaan atau pabrik maupun yang menjual jasa atau tenaganya, harus mendapat perlindungan yang baik atas keselamatan, kesehatan, serta kesusilaan, pe-

\footnotetext{
${ }^{12}$ Raharjo dan Sitomurang, 2006: 22

${ }^{13}$ Susanti, 2000: 9
} 
meliharaan moril kerja serta perlakuan yang sesuai dengan martabat manusia dan moral agama.

Dalam UU No. 13 Tahun 2003 ada 2 Bab yang mengakomodir perlindungan terhadap pekerja wanita, yaitu bab III tentang kesempatan dan perlakuan yang sama. Serta bab X paragraf 3 yang sepenuhnya membahas tentang pekerja wanita. Untuk mengetahui lebih jauh, seberapa dalam UU No. 13 Tahun 2003 mengatur perlindungan terhadap pekerja wanita, maka berikut ini dipaparkan semua pasal yang menyangkut pekerja wanita.

\section{Bentuk-Bentuk Pelanggaran Hukum Yang Umumnya Dialami Oleh Pekerja Wanita. Persoalan Kesejahteraan dan Upah Yang Rendah.}

Agar para pekerja dapat menjalankan pekerjaannya dengan semangat dan bergairah, masalah kesejahteraan dan pengupahan adalah sesuatu yang mutlak. kesejahteraan yang dimaksud antara lain jaminan sakit, hari tua, jaminan kesehatan, jaminan perumahan, jaminan Kematian dan sebagainya. ${ }^{14}$ Secara umum hak dan kewajiban bagi pekerja laki - laki maupun wanita adalah sama, seperti halnya pengaturan jam kerja/lembur, waktu kerja dan istirahat, peraturan tentang istirahat/cuti tahunan, dan pengupahan. Mengenai pengupahan ini sudah diatur secara normatif di dalam perundangan, sehingga bagi perusahaan yang belum atau tidak memenuhi standar yang sudah ditetapkan dapat dikenakan sanksi.

Dalam prakteknya masih ditemui keluhan dari para pekerja wanita mengenai belum terlaksananya secara optimal peraturan tersebut, keluhan itu antara lain Tidak diberi kesempatan untuk mendapatkan pendidikan tambahan atas beban perusahaan, Adanya diskriminasi atas pengupahan yang sama untuk masa kerja yang sama dan pekerjaan yang sama nilainya, Pekerja wanita dianggap lajang sehingga tidak mendapat tunjangan keluarga, meskipun kenyataannya dia telah bersuami dan mempunyai anak.

\footnotetext{
${ }^{14}$ Gunarto, 2002: 24
}

Diskriminasi upah terjadi antara lain dikarenakan oleh pandangan yang menilai bahwa pekerja wanita hanya sebagai sumber pelengkap/tambahan bagi perekonomian keluarga, sehingga pekerja wanita menerima upah yang lebih rendah dari laki-laki. Akibat lebih jauh adalah pemotongan pajak yang lebih besar pada pekerja wanita dibandingkan laki-laki karena pada pekerja laki-laki pajak dikurangi dengan tunjangan istri dan anak. $^{15}$

Pembedaan upah karyawan laki-laki dan wanita untuk pekerjaan yang sama sering kali menggunakan pembenaran bahwa "wanita bukan pencari nafkah utama" atau "wanita adalah tanggungan suami". Penghapusan hak karyawan wanita untuk mendapat tunjangan keluarga dan kesehatan bagi dirinya dan keluarganya, juga memakai pembenaran yang sama (Jehani, 2006: 8). Hukum ketenagakerjaan di Indonesia tidak membenarkan diskriminasi tersebut, namun dalam prakteknya sering dipelintir oleh pengusaha. Fakta bahwa Indonesia telah meratifikasi Convention on the Elimination of All Forms of Discrimination against Women (CEDAW) seolah terlupakan.

Hal lain yang juga perlu diperhatikan adalah bahwa dalam penetapan upah minimum regional sendiri, yang digunakan sebagai standar adalah buruh laki-laki dengan hitungan hidup lajang, yang memiliki kebutuhan berbeda dari buruh wanita. Dalam penentuan upah tersebut, laporan menyebutkan, tidak dimasukkan kebutuhan spesifik wanita seperti pembelian $\mathrm{BH}$ dan pembalut wanita. Hal yang kelihatannya sepele ini, berakibat pada upah riil buruh wanita yang secara riil menjadi lebih kecil karena dikurangi untuk memenuhi kebutuhan tersebut. ${ }^{16}$

\section{Diskriminasi Dalam Hak-Hak Khusus Pekerja Wanita.}

Pada dasarnya peraturan ketenagakerjaan melindungi hak-hak pekerja pria dan wanita. Namun disebabkan oleh kodrat wanita yang berbeda dengan laki-laki maka ada be-

\footnotetext{
${ }^{15}$ Munti, 1999: 37

${ }^{16}$ Tim Rifka Annisa, 2003: 6
} 
158 | de Jure, Jurnal Syariah dan Hukum, Volume 2 Nomor 2, Desember 2010, hlm. 150-161

berapa pengaturan yang khusus mengenai hak-hak pekerja wanita. Hak-hak khusus pekerja wanita ini meliputi cuti haid, hamil dan melahirkan. Kesemua hak-hak khusus tersebut telah ditetapkan dalam beberapa rangkaian peraturan antara lain Convention on the Elimination of All Forms of Discrimination against Women (CEDAW), UU RI No. 13 Tahun 1993 Tentang Ketenagakerjaan, Peraturan Menteri Pekerja No. 03/Men/1989 dan lain-lain.

\section{Cuti Haid}

Bagi wanita yang normal dan sehat, pada usia tertentu akan mengalami haid. Di dalam prakteknya, banyak wanita yang sedang dalam masa haid tetap bekerja tanpa gangguan apapun. Tetapi kalau keadaan fisiknya tidak memungkinkan sehingga yang bersangkutan tidak dapat melakukan pekerjaan tersebut. Hal ini diatur dalam UU No. 13 Tahun 2003 Pasal 81 ayat (1) yang berbunyi: "Pekerja/buruh wanita yang dalam masa haid merasakan sakit dan memberitahukan kepada pengusaha, tidak wajib bekerja pada hari pertama dan kedua pada waktu haid.

Selanjutnya Sadli, mengatakan bahwa: "meskipun ada negara-negara yang tidak lagi memberikan cuti haid, tetapi untuk pekerja Wanita, hal ini harus diberikan". ${ }^{17}$ Singkatnya, alasan untuk tetap diadakannya cuti haid ini adalah bahwa ketika haid datang, pekerja wanita yang bekerja pada satu posisi selama beberapa jam terus menerus akan merasa sangat tidak nyaman dalam bekerja.

Namun dalam pelaksanaannya tidak semua perusahaan memberikan dengan suka rela. Sebagai salah satu contoh adalah apa yang kemukakan oleh salah seorang mantan pekerja pada sebuah perusahaan bahwa: "Ada pabrik yang menuntut buruh wanitanya memperlihatkan (maaf) pembalut yang dia pakai untuk memastikan bahwa si buruh memang sedang haid hari pertama dan kedua. Bila dianggap haid itu bukan hari pertama dan kedua, cutinya ditolak. ${ }^{18}$

17 Sadli, 2007: 3

18 Apong, 1998: 5
Cuti Hamil, Melahirkan, Gugur Kandungan dan Kesempatan Menyusui.

Bagi pekerja wanita yang hamil, dilindungi oleh UU No. 13 Tahun 2003 Pasal 82 ayat (2) dan (3) yang menyatakan: 1) Pekerja/buruh wanita berhak memperoleh istirahat selama 1,5 (satu setengah) bulan sebelum saatnya melahirkan anak dan 1,5 (satu setengah) bulan sesudah melahirkan menurut perhitungan dokter kandungan atau bidan, 2) Pekerja/buruh wanita yang mengalami keguguran kandungan berhak memperoleh istirahat 1,5 (satu setengah) bulan atau sesuai dengan surat keterangan dokter kandungan atau bidan.

Ketentuan tersebut dinyatakan berlaku dengan peraturan pemerintahan No. 4 tahun 1951 Pasal 1 butir 1 yang berbunyi bagi pekerja yang akan menggunakan hak cutinya diwajibkan: a) Mengajukan permohonan yang dilampiri surat keterangan dokter, bidan atau keduanya jika tidak ada, dapat dari pegawai pamong praja atau sederajatnya camat. b) Permohonan diajukan selambatnya 10 hari sebelum waktu cuti mulai.

Cuti sebelum saatnya melahirkan dimungkinkan untuk diperpanjang apabila ada keterangan dokter yang menerangkan bahwa yang bersangkutan perlu mendapatkan istirahat untuk menjaga kehamilannya. Perpanjangan waktu istirahat sebelum melahirkan memungkinkan sampai selama-lamanya tiga bulan.

Seorang pekerja wanita tidak bisa di-PHK karena alasan menikah, sedang hamil dan melahirkan. Hal ini diatur dalam Peraturan Menteri Pekerja No. 03/Men/1989. Selanjutnya dalam UU Pekerja No. 13 Tahun 1993 Pasal 76 ayat (2) menyebutkan bahwa:

Pengusaha dilarang mempekerjakan pekerja/buruh wanita hamil yang menurut keterangan dokter berbahaya bagi kesehatan dan keselamatan kandungannya maupun dirinya apabila bekerja antara pukul 23.00 s.d. 07.00. Pekerja yang hamil harus mendapat cuti dengan bayaran atau tunjangan sosial sebanding tanpa kehilangan pekerjaannya. Tempat penitipan anak di tempat kerja pun menjadi se- 
suatu yang harus diadakan oleh perusahaan, dan memberi perlindungan khusus kepada wanita selama hamil pada jenis pekerjaan yang terbukti berbahaya bagi mereka.

Sedangkan untuk menyusui diatur dalam Pasal 83 UU No. 13 Tahun 2003 yaitu: Pekerja/buruh wanita yang anaknya masih menyusu harus diberi kesempatan sepatutnya untuk menyusui anaknya jika hal itu harus dilakukan selama waktu kerja. Yang dimaksud dengan kesempatan sepatutnya dalam Pasal ini adalah lamanya waktu yang diberikan kepada pekerja/buruh wanita untuk menyusui bayinya dengan memperhatikan tersedianya tempat yang sesuai dengan kondisi dan kemampuan perusahaan, yang diatur dalam peraturan atau perjanjian kerja bersama.

\section{Mengalami Pelecehan Seksual.}

Istilah Pelecehan seksual (sexual harassment) memang cukup populer dalam masyarakat Indonesia, istilah tersebut sebenarnya telah ada sejak pertengahan tahun 70-an. Munculnya istilah ini marak seiring dengan kesadaran kaum wanita akan hak dan derajatnya. Hal ini karena masalah pelecehan seksual tidak dapat dipisahkan dari masalah diskriminasi gender.

Dalam bukunya yang komprehensif yang membahas tentang pelecehan seksual, Farley menyebutkan bahwa pelecehan seksual terhadap wanita di tempat kerja telah tercatat sejak pertama kali wanita memasuki pasar pekerja. Artinya, pelecehan seksual terhadap wanita di tempat kerja bukanlah suatu persoalan yang baru, tetapi sudah setua umur sejarah wanita memasuki dunia kerja publik, yaitu sejak kapitalisme berkembang.

Menurut pengertian Kamus Besar Bahasa Indonesia kata pelecehan merupakan bentuk kata benda dari kata kerja melecehkan yang berarti menghinakan, memandang rendah, mengabaikan. Sedangkan kata seksual memiliki arti hal yang berkenan dengan seks atau jenis kelamin, hal yang berkenan dengan perkara persetubuhan antara pria dan wanita. Dengan demikian, berdasarkan pengertian tersebut maka pelecehan seksual diartikan sebagai bentuk penghinaan atau memandang rendah seseorang karena hal-hal yang berkenaan dengan seks, jenis kelamin atau aktivitas seksual antara pria dan wanita.

Sedangkan menurut Eliyawati, pelecehan seksual yaitu semua tindakan seksual atau kecenderungan bertindak secara seksual yang bersifat intimidasi non fisik (kata-kata, bahasa, gambar) atau fisik (gerakan yang kasat mata seperti memegang, menyentuh, meraba, mencium bagian-bagian tubuh tertentu) yang dilakukan oleh seseorang atau kelompok terhadap seseorang atau kelompok lain. Tindakan tersebut dipahami sebagai tindakan merendahkan, mengaibkan, dan mencemarkan keberadaan pihak yang bersangkutan. Yang mana tindakan tersebut dapat berupa siulan, colekan, kata-kata tidak senonoh. ${ }^{19}$

Sesuai dengan pengertian yang di kemukakan di atas maka dapat disimpulkan bahwa pelecehan seksual merupakan bentuk tingkah laku verbal maupun non verbal yang dilakukan sekali atau lebih oleh pelakunya untuk tujuan kesenangan seksual yang tidak diinginkan dan dikehendaki oleh korbannya (tidak timbal balik) dan dianggap sebagai sesuatu yang dapat mengancam kesejahteraannya secara fisik, psikologis, sosial dan ekonomi.

Pelecehan seksual umumnya lebih banyak terjadi terhadap pekerja wanita, meskipun dalam satu dua kasus langka, ada juga pekerja lelaki yang menjadi korban. Akar dari pelecehan seksual di tempat kerja, sama dengan basis dari berbagai diskriminasi, penindasan dan ketidakadilan lainnya yang dialami oleh kaum wanita, seperti kekerasan dalam rumah tangga, diskriminasi upah, perkosaan, pelacuran dan perdagangan wanita. Penyebab utamanya adalah adanya kekuasaan dan ketidaksetaraan ekonomi serta pandangan seksis yang meluas dalam masyarakat. Pelecehan seksual di tempat kerja adalah hal yang sering terjadi namun jarang diungkapkan. Pekerja wanita harus menanggung risiko atau beban pelecehan dari dua arah: Pertama, pelecehan bisa terjadi dari atasannya. Pelecehan seksual ini terjadi ketika seseorang yang dengan "kekuasaan19 Eliyawati, 2005: 56 
nya" bisa memanfaatkan kedudukannya itu untuk mendesak orang lain dengan tindakan seksual yang tidak dikehendaki. Kedua, pelecehan terjadi dari sesama pekerja terutama pekerja laki-laki. Atasan yang memperlakukan pekerja wanita secara diskriminatif akan memicu situasi dimana para pekerja laki-laki merasa bahwa ini adalah hal "wajar", karenanya kepentingan menghapus terjadinya pelecehan seksual bukan semata karena pekerja wanita berhak atas suasana dan syarat-syarat kerja yang setara dan adil, namun juga karena pelecehan seksual memecah belah persatuan dan kekompakan kaum pekerja, dan menjerumuskan para pekerja dalam situasi saling curiga dan konflik di antara mereka.

Bentuk-bentuk perilaku pelecehan seksual yang sering terjadi dan dikategorikan sebagai pelecehan seksual di antaranya: 1) Tingkah laku dan komentar yang berkenaan dengan peran jenis kelamin wanita (gender harassmen), 2) Ajakan untuk kesenangan seksual yang tidak dikehendaki dan memaksa namun tidak memiliki sanksi apapun (seductive behavior), 3) Permintaan untuk melakukan kegiatan seksual atau hal yang berhubungan dengan disertai janji atau imbalan tertentu (sexual bribery), 4) Pemaksaan untuk melakukan hubungan seksual dengan disertai ancaman hukuman (sexual coercion), 5) Kejahatan seksual dan pelanggaran hukum yang dilakukan secara terang-terangan (sexual assault). ${ }^{20}$

\section{Kesimpulan}

Pertama, Sesungguhnya pekerja wanita menyadari bahwa masih ada perjanjian kerja yang merugikan dirinya, karena terkadang tidak semua hak khusus pekerja wanita dicantumkan dalam perjanjian kerja tersebut. Namun mereka pasrah dengan perjanjian kerja tersebut karena faktor posisi tawar yang lemah dan keterbatasan lapangan kerja. Kedua, Dengan adanya UU No. 13 Tahun 2003, beberapa peraturan menteri lainnya

20 Kusmana, 2007: 4 dan hukum-hukum internasional yang telah ada, semestinya kasus pelanggaran hukum terhadap pekerja wanita akan semakin jarang terdengar. Namun pada kenyataannya pelaksanaan dari semua aturan-aturan tersebut terkadang tidak dilaksanakan sepenuhnya. Ketiga, Umumnya pekerja wanita yang dilanggar hak-haknya, ataupun mengalami pelecehan di tempat kerja lebih banyak "diam" dan berusaha "melupakan" pelanggaran-pelanggaran yang mereka alami.

\section{Saran}

Dengan mengacu dari hasil penelitian kepustakaan yang selama ini dilakukan, serta ulasan-ulasan pembahasan pada bab-bab sebelumnya, maka saran yang dapat diberikan pada penulisan skripsi ini yaitu: Pertama, Berdasarkan hasil bedah UU No. 13 Tahun 2003 Tentang Tenaga Kerja, ditemui hanya ada 5 pasal yang mengatur secara khusus bagi pekerja wanita. Harus diakui bahwa jumlah ini sangatlah sedikit, dan menjadi lebih baik jika dibuatkan peraturan setingkat UU yang mengatur secara dan detail tentang perlindungan hukum terhadap pekerja wanita beserta permasalahannya, lengkap dengan metode pembuktian, bahkan bentukbentuk rehabilitasi dan terapi jika sekiranya dibutuhkan, Kedua, Keterlibatan yang paling utama bagi pemerintah adalah dalam bentuk pembuatan dan penerapan berbagai bentuk peraturan yang memberi peluang untuk diadilinya kasus pelecehan seksual sebagai kasus pidana, setara dengan pidana-pidana umum lainnya, Ketiga, Penyadaran mengenai kesetaraan gender dan pandangan mengenai kedudukan yang setara dalam kerja juga perlu ditanamkan sejak dini pada semua lapisan dan kalangan. Selain itu perlu ditanamkan sejak tingkat pendidikan dasar bahwa pelecehan seksual merupakan tindakan yang salah, dan dikenalkan pula bentuk-bentuk perilaku pelecehan seksual kepada peserta didik apa, mengapa dan bagaimana mengatasi pelecehan seksual. 


\section{DAFTAR RUJUKAN}

Apeldoorn, L. J. Van. 1982. Pengantar Ilmu Hukum (Inleiding tot de Studie van Het Nederlandse Recht). Jakarta: Pradnya Paramita.

Apong, Herlina. 1998. Kekerasan terhadap Perempuan di Dunia Kerja. Depok: Pusat Kajian Wanita dan Jender Universitas Indonesia.

Asikin, Zainal, dkk. 1993. Dasar-Dasar Hukum Perburuhan. Jakarta: Rajawali pers.

Eliyawati. tth. Artikel: Awas Pelecehan Seksual di Tempat Kerja. Sumber: http://fspmipemi.multiply.com

Gunarto, Suhardi. 2002. Peranan Hukum Dalam Pembangunan Ekonomi. Yogyakarta: Universitas Atmajaya.

Hadikusuma, Hilman. 1995. Metode Pembuatan Kertas Kerja atau Skripsi Hukum. Bandung: Mandar Maju.

Hakim, Abdul. 2006. Aspek Hukum Pengupahan, Bandung: Citra Aditya Bakti.

Hakim, Abdul. 2007. Pengantar Hukum Ketenagakerjaan Indonesia, Bandung: Citra Aditya Bakti.

Hanartani. 2002. Artikel: Tajuk Rencana Undang-undang Perlindungan Pekerja Wanita. Sumber: http://www.nakertrans.go.id.

Husni, Lalu. 2003. Hukum Ketenagakerjaan Indonesia. Jakarta: Rajawali Pers.

Kusmana, Ganjar. 2007. Artikel: Pelecehan Seksual Di Tempat Kerja. Sumber: http:// www.hukumonline.com.

Muhammad, Abdul kadir. 2004. Hukum dan
Penelitian Hukum Cet. 1. Bandung: Citra Aditya Bakti.

Munti, Ratna B. 2007. Refleksi dan Catatan Kerja LBH APIK Jakarta Tahun 2006. Sumber: http://www.lbh-apik.com

Munti, Ratna B. 1999. Perempuan Sebagai Kepala Rumah Tangga. Jakarta: Lembaga Kajian agama dan Gender.

Pambudy, Ninuk M. 2006. Artikel: Memahami Konsep Diri. Harian Kompas dan Harian swara. ttp.

Raharjo dan Sitomurang. 2006. Artikel: Perlindungan Hukum Bagi Pekerja Wanita. Sumber: http://www.lppm.uns.ac.id.

Sadli, Saparinah. 2007. Artikel: Kesetaraan Gender. Sumber: Situs Resmi Kementrian Pemberdayaan Perempuan.

Soekanto, Soerjono dan Sri Mamudji. 1995. Penelitian Hukum Normatif Suatu Tinjauan Singkat. Jakarta: Raja Grafindo Persada.

Suksesyadi. 2008. Artikel: Perlindungan Terhadap Perempuan Pekerja.. Sumber: http:// www.bangkapos.com.

Sunggono, Bambang. 2003. Metodologi Penelitian Hukum. Jakarta: Raja Grafindo Persada.

Susanti, Dewi M. tth. Artikel: Peranan Perempuan Dalam Upaya Penanggulangan Kemiskinan. Sumber: http://www. bappeda-purwakarta.or.id

Tim Rifka Annisa. 2003. Kumpulan Artikel, Yogyakarta: Women's Crisis Center. 